\title{
The effects of azadirachtin and emamectin benzoate insecticides as organic pollutants on experimental rats
}

\author{
Abd El-Rahman ; A.A* .; Foda, F.F.A.* ; \\ Mekawi, E.M.* and Refaee, L.A.** Ali, M.Z.M.*** \\ * Agric. Biochemistry Dept., Fac. of Agric., Benha University, Egypt. \\ ** Medical Biochem. Dept., Theodor Bilharz Researches Institute, Egypt. \\ *** New Kasr El-Ainy-Teaching Hospital, Egypt.
}

\begin{abstract}
The present study aimed to throw light on the efficiency of two insecticides, Azadirachtin and Emamectin Benzoate. Chemical components of serum blood and histopathological were examined by three different doses treated orally $\left(1 / 100,1 / 150\right.$ and1/225 $\left.\mathrm{LD}_{50}\right)$ of adult mature male albino rats weighting (100-120) $\mathrm{g}$ for 60 days. The results showed that there were significant increases of ALT,AST, urea and creatinine in the treatment of Azadirachtin more than Emamectin Benzoate and control. On the other hand there were significant decreses in protein content in the treatment of Azadirachtin more than Emamectin Benzoate on comparision with control. Histological studies were certain of chemical analysis results.At the end all the results indicated the toxic nature of the Azadirachtin insecticide were more than Emamectin Benzoate on albino rats.
\end{abstract}

Keywords: Azadirachtin, Emamectin Benzoate, Toxicity, Kidney, Liver.

\section{Introduction}

Analysis of pesticide residues plays an important role in food quality for evaluating food safety and possible risks to human health. Pesticide residues in food have historically lagged far behind many comparable hazards as a cause for puplic health concern and action (Correia et al., 2000 and Eskenazi et al., 2008). Pesticide residues contaminating food is the problem focused worldwide because of its direct implications on human health and international trade (Sanborn et al., 2004).

Emamectin Benzoate (4-deoxy-4-epimethylamino-4deoxya- vermectin B1 benzoate, is amacrocyclic lactone chemical that was synthesized from chemical modification of avermectin B1. Emamectin Benzoate is a mixture of two analogs (B1a:B1b, 9:1), which differ by one methylene $\left(\mathrm{CH}_{2}\right)$ unit on the $\mathrm{C}-25$ side chain, where in B1a contains a sec-butyl group and B 1b contains an isopropyl group (Kang et al. 2001). Azadirachtin is a limonoid secondary metabolite $\left(\mathrm{C}_{35}\right.$ $\mathrm{H}_{44} \mathrm{O}_{16}$ ), a tetra notri terpenoid) of the Indian Neem tree (Azadira chtaindica A. Juss). It is extracted from the soft pressed neem kernels (neem cake) after appropriate solvent extraction, and is available as a yellowish brown powder (technical grade Azadirachtin) at concentration of 12-26\% (Immaraju, 1998 and Seljasena and Meadow, 2006). This technical grade material is used for the production of a wide range of commercial formulations exhibiting good efficancy against more than 400 insect species (Sharma et al., 2006 and Ishaaya et al., 2007).
Proteins are important organic substances required by organisms in tissue building and play an important role energy metabolism (Pang-Hang et al., 2008).

The aim of this study is to evaluate effects of Azadirachtin and Emamectin Benzoate on experimental rats by three different doses which include, liver functions, kidney functions and histopathological examination of liver and kidney were studied.

\section{Materials and Methods}

Diagnostic kits were obtained from Bio-Merieuex Laboratory Reagents and Products, France, were used for determination of serum urea, creatinine, uric acid, total protein, albumin, Globulin, A/G ratio, ALP and transaminase (AST, ALT). All chemical used in this study were analytical grade.

The pesticides, Azadirachtin and Emamectin Benzoate were used and obtained from the plant protection Research Institute (Dokki, Giza, Egypt).

\section{Experimental animal:}

The present work was under taken to study the effect of insecticides on chemical components of blood and histopathological examination of albino rats. A total of 42 adult mature male albino rats, weighting (100-120 g) were used in the present study. They were fed in the animal house (National Research Center) Giza- Egypt.

\section{Animal Grouping:}

Animals were classified into 7 groups of 6 rats each composed as Follows:

Group (1): Without treatment and kept as a control. 
Group (2): Administered orally $1 / 100 \quad \mathrm{LD}_{50}$ of Azadiraction (50) mg/kg, B.wt) day after day for two months (60 days).

Group (3): Administered orally $1 / 150 \quad \mathrm{LD}_{50}$ of Azadiraction (33.3 mg/kg B.wt).

Group (4): Administered orally $1 / 225 \mathrm{LD}_{50}$ of Azadiraction ( $22.2 \mathrm{mg} / \mathrm{kg} \mathrm{b.wt).}$

Group (5): Administered orally 1/100 $\mathrm{LD}_{50}$ of Emamectin Benzoate (15 mg/kgB.wt).

Group (6): Administered orally 1/150 $\mathrm{LD}_{50}$ of Emamectin Benzoate (10mg/kg B.wt.).

Group (7): was administered orally $1 / 225 \mathrm{LD}_{50}$ of of Emamectin Benzoate (6, $7 \mathrm{mg} / \mathrm{kg}$ B.wt.).

Blood samples were collected into a plain tube for serum preparation and assay of the chemical parameter of blood samples included liver and kidney function testes.

At the end of the experiment the rats were scarified and the post mortem findings were recorded. Autopsy samples were taken from the liver, kidney and pancreas of rats in different groups and fixed in $10 \%$ formal saline $24 \mathrm{~h}$. The obtained tissue sections were collected on glass slides, deparaffinized and stained by hematoxylin and eosin stain then examined through the electric light microscope (Banchroft et al., 1996). Aspartate aminotransferase (AST) and alanine aminotransferase (ALT) activities were measured according to the method described by Reitman and Frankel (1957). Serum alakaline phosphatase was determined according to the method described by Tietz et al. (1983). Serum total proteins were determined by method performed by Doumas (1975). Serum albumin and globulin were determined according to the method described by Doumas et al. (1971). Urea levels were determined according to the method described by Tabacco $\boldsymbol{e t}$ al . (1979). Creatinine levels content were determined according to the method described by Henery $\boldsymbol{e t}$ al . (1974). Serum uric acid was determined using Enzymatic-colorimetric method according to (Haisman and Muller, 1977).

\section{Statistical analysis:}

The statistical analysis was carried out carried out using ANOVA with one factor under significance level of 0.05 for the whole results using SPSS var. 19 and data were treated as complete randomization design according to Steel et al. (1997). Multiple comparisons were carried out applying LSD and Duncan.

\section{Results and Discussion}

1. Biochemical effects of Azadirachtin and Emamectin Benzoate on experimental rats:

1.1. Effect of Azadirachtin and Emamectin Benzoate on liver function:
The effect of oral administration of Azadirachtin and Emamectin Benzoate residues on activities of liver enzymes (AST, ALT, and ALP) of rats were investigated and the obtained results are tabulated in Table (1).

From the results, it could be observed that the enzyme activities in serum of the control rats group were found to be $(6.00 \pm 0.37,5.83 \pm 0.48$ and $110.83 \pm 4.36 \mathrm{IU} / \mathrm{ml}$ after two months for ASL, ALT and ALP, respectively.

The serum AST, ALT and ALP activities of Azadirachtin in G2, G3 and G4 were found to be $(27.20 \pm 0.79,21.40 \pm .76$ and $18.83 \pm 1.01 \mathrm{IU} / \mathrm{ml})$ for AST, $(41.8 \pm 0.87,30.00 \pm 1.24$ and $25.83 \pm 1.14 \mathrm{IU} / \mathrm{ml})$ for ALT, $(221.00 \pm 5.23,198.00 \pm 4.20$ and 165.83 $\pm 4.17 \mathrm{IU} / \mathrm{l})$ for ALP, respectively. These results were significantly increased compared with G1 (control). While the serum AST ALT and ALP activities of Emamectin Benzoate in G5, G6 and G7 were found to be $(17.83 \pm 0.70,11.00 \pm 0.37$ and $9.00 \pm 0.37 \mathrm{IU} / \mathrm{ml})$ for AST. $(24.33 \pm 0.76,11.00 \pm 0.77$ and $9.83 \pm 0.60 \mathrm{IU} / \mathrm{ml})$ for ALT and $(185.83 \pm 7.12$, $177.50 \pm 8.34$ and $145.83 \pm 6.88 \mathrm{IU} / \mathrm{ml})$ for ALP, respectively. These results significantly increased compared with G1 (control). But the mean values of serum transaminase activities of AST, ALT and ALP showed insignificant increase in Azadirachtin more than Emamectin Benzoate and control. These results are in agreement with those reported by Dafalla $\boldsymbol{e t}$ al. (2012), Hassina et al. (2013), Abdel-Hafez and Osman (2013) and Baligar et al. (2014).

1.2. Effect of Azadirachtin and Emamectin Benzoate on serum total proteins, albumin, and globulin and $A / G$ ratio of rats serum

The mean values of serum total proteins, albumin, globulin and $\mathrm{A} / \mathrm{G}$ ratio of rats were assayed and the obtained data are presented in Table (2). 
Table 1. Effect of Azadirchtin and Emamectin Benzoate residues on liver function of experimental rats.

\begin{tabular}{|c|c|c|c|c|c|c|c|c|}
\hline \multirow{2}{*}{ Parameter } & \multirow{2}{*}{$\begin{array}{c}\text { Period } \\
\text { for dose }\end{array}$} & \multirow{2}{*}{$\begin{array}{c}\text { Control } \\
\text { G1 }\end{array}$} & \multicolumn{3}{|c|}{ Azadirachtin } & \multicolumn{3}{|c|}{ Emamectin Benzoate } \\
\hline & & & G2 & G3 & G4 & G5 & G6 & G7 \\
\hline AST & Before & $5.67 \pm 0.33^{\mathrm{aBC}}$ & $6.33 \pm 0.88^{\mathrm{aC}}$ & $5.67 \pm 0.88^{\mathrm{aBC}}$ & $5.33 \pm 0.88^{\mathrm{aBC}}$ & $5.67 \pm 0.88^{\mathrm{aBC}}$ & $3.67 \pm 0.88^{\mathrm{aA}}$ & $4.67 \pm 0.88^{\mathrm{aAB}}$ \\
\hline (IU/l) & After & $6.00 \pm 0.37^{\mathrm{aA}}$ & $27.20 \pm 0.79^{\mathrm{bF}}$ & $21.40 \pm 0.76^{\mathrm{bE}}$ & $18.83 \pm 1.01^{\mathrm{bD}}$ & $17.83 \pm 0.70^{\mathrm{bD}}$ & $11.00 \pm 0.37^{\mathrm{bC}}$ & $9.00 \pm 0.37^{\mathrm{bB}}$ \\
\hline ALT & Before & $3.00 \pm 0.58^{\mathrm{aA}}$ & $6.33 \pm 0.67^{\mathrm{aC}}$ & $4.67 \pm 0.33^{\mathrm{aB}}$ & $8.33 \pm 0.88^{D}$ & $5.00 \pm 1.15^{\mathrm{aBC}}$ & $5.33 \pm 1.20^{\mathrm{aBC}}$ & $3.00 \pm 0.58^{\mathrm{aA}}$ \\
\hline (IU/I) & After & $5.83 \pm 0.48^{\mathrm{bA}}$ & $41.8 \pm 0.87^{\mathrm{bE}}$ & $30.00 \pm 1.24^{\mathrm{bD}}$ & $25.83 \pm 1.14^{\mathrm{bC}}$ & $24.33 \pm 0.76^{\mathrm{bC}}$ & $11.00 \pm 0.77^{b B}$ & $9.83 \pm 0.60^{b B}$ \\
\hline ALP & Before & $100.00 \pm 2.52^{\mathrm{aA}}$ & $116.67 \pm 4.41^{\mathrm{aCD}}$ & $101.00 \pm 2.08^{\mathrm{aAB}}$ & $103.33 \pm 1.67^{\mathrm{aAB}}$ & $125.00 \pm 7.64^{\mathrm{aD}}$ & $114.33 \pm 7.88^{\mathrm{aCD}}$ & $111.33 \pm 6.33^{\mathrm{aBC}}$ \\
\hline (IU/I) & After & $110.83 \pm 4.36^{\mathrm{bA}}$ & $221.00 \pm 5.23^{b F}$ & $198.00 \pm 4.20^{\mathrm{bE}}$ & $165.83 \pm 4.17^{\mathrm{bC}}$ & $185.83 \pm 7.12^{\mathrm{bD}}$ & $177.50 \pm 8.34^{\mathrm{bD}}$ & $145.83 \pm 6.88^{b B}$ \\
\hline
\end{tabular}

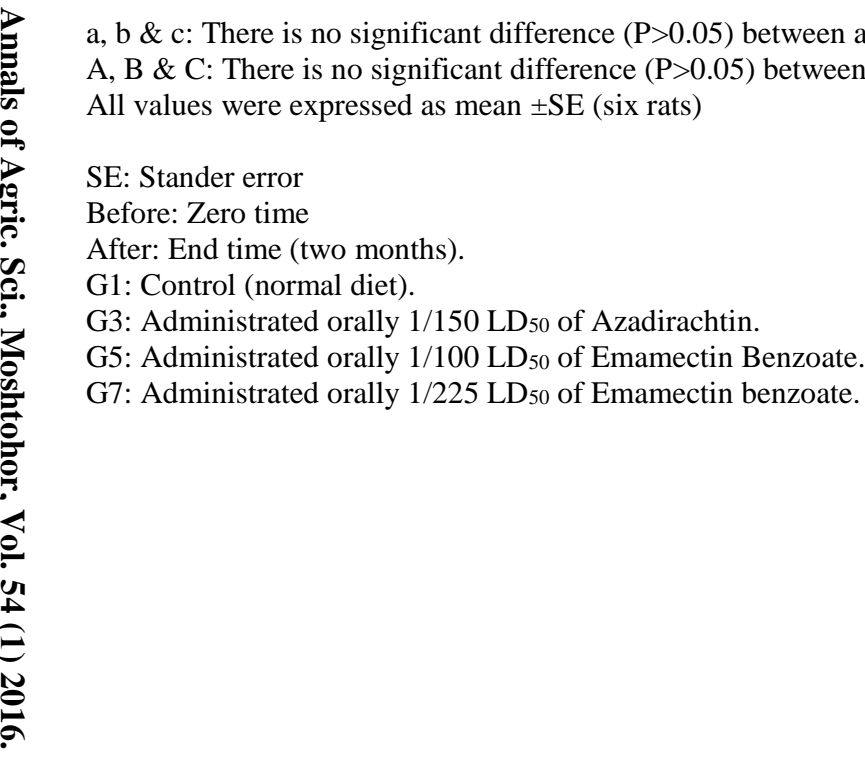

G2: Administrated orally 1/100 LD50 of Azadirachtin.

G4: Administrated orally 1/225 LD50 of Azadirachtin.

G6: Administrated orally 1/150 LD 50 of Emamectin Benzoate. 
Table 2. Effect of Azadirchtin and Emamectin Benzoate residues on serum total protein, albumin and globulin of experimental rats.

\begin{tabular}{|c|c|c|c|c|c|c|c|c|}
\hline \multirow{2}{*}{ Parameter } & \multirow{2}{*}{$\begin{array}{c}\text { Period } \\
\text { for } \\
\text { dose } \\
\end{array}$} & \multirow{2}{*}{$\begin{array}{c}\text { Control } \\
\text { G1 }\end{array}$} & \multicolumn{3}{|c|}{ Azadirachtin } & \multicolumn{3}{|c|}{ Emamectin Benzoate } \\
\hline & & & G2 & G3 & G4 & G5 & G6 & G7 \\
\hline \multirow{6}{*}{$\begin{array}{c}\text { Total protein } \\
\text { (g/dl) } \\
\text { Albumin } \\
\text { (g/dl) } \\
\text { Globulin } \\
\text { (g/dl) }\end{array}$} & Before & $7.20 \pm 0.15^{b B}$ & $6.97 \pm 0.12^{\mathrm{bAD}}$ & $6.77 \pm 0.15^{\mathrm{aAD}}$ & $7.47 \pm 0.12^{\mathrm{bC}}$ & $7.30 \pm 0.20^{\mathrm{bBC}}$ & $7.27 \pm 0.15^{\mathrm{bBC}}$ & $7.40 \pm 0.21^{\mathrm{bBC}}$ \\
\hline & After & $6.95 \pm 0.09^{\mathrm{aCD}}$ & $6.72 \pm 0.07^{\mathrm{aAB}}$ & $6.92 \pm 0.12^{\mathrm{bBC}}$ & $7.27 \pm 0.14^{\mathrm{aE}}$ & $6.63 \pm 0.09^{\mathrm{aA}}$ & $7.15 \pm 0.08^{\mathrm{aDE}}$ & $7.02 \pm 0.03^{\mathrm{aCD}}$ \\
\hline & Before & $4.37 \pm 0.09^{\mathrm{bA}}$ & $4.63 \pm 0.09^{b B}$ & $4.20 \pm 0.17^{\mathrm{bA}}$ & $4.70 \pm 0.21^{\mathrm{bBC}}$ & $4.57 \pm 0.09^{b B}$ & $4.60 \pm 0.23^{b B}$ & $4.80 \pm 0.15^{b C}$ \\
\hline & After & $4.18 \pm 0.10^{\mathrm{aE}}$ & $3.06 \pm 0.06^{\mathrm{aA}}$ & $3.36 \pm 0.04^{\mathrm{aC}}$ & $3.98 \pm 0.08^{\mathrm{aD}}$ & $3.20 \pm 0.04^{\mathrm{aAC}}$ & $3.87 \pm 0.13^{\mathrm{aD}}$ & $4.20 \pm 0.12^{\mathrm{aE}}$ \\
\hline & Before & $2.83 \pm 0.09^{\mathrm{aD}}$ & $2.33 \pm 0.03^{\mathrm{aA}}$ & $2.57 \pm 0.27^{\mathrm{aABC}}$ & $2.77 \pm 0.19^{\mathrm{aCD}}$ & $2.40 \pm 0.06^{\mathrm{aAB}}$ & $2.67 \pm 0.09^{\mathrm{aC}}$ & $2.60 \pm 0.20^{\mathrm{aB}}$ \\
\hline & After & $2.77 \pm 0.12^{\mathrm{aA}}$ & $3.66 \pm 0.05^{\mathrm{bC}}$ & $3.56 \pm 0.13^{\mathrm{bB}}$ & $3.28 \pm 0.20^{\mathrm{bB}}$ & $3.43 \pm 0.07^{\mathrm{bBC}}$ & $3.28 \pm 0.13^{\mathrm{bB}}$ & $2.87 \pm 0.08^{\mathrm{bA}}$ \\
\hline \multirow{2}{*}{ A/G ratio } & Before & $1.53 \pm 0.04^{\mathrm{aA}}$ & $1.98 \pm 0.02^{\mathrm{bC}}$ & $1.67 \pm 0.21^{\mathrm{bAB}}$ & $1.72 \pm 0.19^{\mathrm{bAB}}$ & $2.07 \pm 0.24^{\mathrm{bC}}$ & $1.73 \pm 0.15^{\mathrm{bAB}}$ & $1.86 \pm 0.16^{\mathrm{bBC}}$ \\
\hline & After & $1.53 \pm 0.09^{\mathrm{aC}}$ & $1.00 \pm 0.16^{\mathrm{aA}}$ & $0.95 \pm 0.04^{\mathrm{aA}}$ & $1.24 \pm 0.10^{\mathrm{aB}}$ & $0.93 \pm 0.02^{\mathrm{aA}}$ & $1.19 \pm 0.08^{\mathrm{aB}}$ & $1.51 \pm 0.11^{\mathrm{aC}}$ \\
\hline
\end{tabular}

$\mathrm{a}, \mathrm{b} \& \mathrm{c}$ : There is no significant difference $(\mathrm{P}>0.05)$ between any two means, within the same column have the same superscript letter

A, B \& C: There is no significant difference $(\mathrm{P}>0.05)$ between any two means for the same attribute, within the same row have the same superscript letter.

All values were expressed as mean $\pm \mathrm{SE}$ (six rats)

SE: Stander error

Before: Zero time

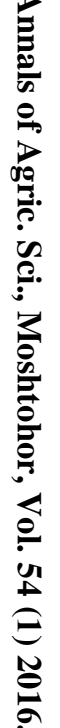

G2: Administrated orally 1/100 LD50 of Azadirachtin.

G1: Control (normal diet).

G3: Administrated orally $1 / 150 \mathrm{LD}_{50}$ of Azadirachtin.

G4: Administrated orally 1/225 LD 50 of Azadirachtin.

G5: Administrated orally 1/100 LDso of Emamectin Benzoate.

G7: Administrated orally 1/225 LD 50 of Emamectin benzoate.

G6: Administrated orally 1/150 LD50 of Emamectin Benzoate. 
From the obtained results of the G1 (control) were found to be $6.95+0.09,4.18+0.10,2.77+0.12$ and $1.53+0.09 \mathrm{~g} / \mathrm{dl}$, respectively, after two months. While, the result in G2 and G5 were significantly decreased compared with control group and other groups were non- significant differentiation comparing with control rats group.

From the same table, the mean values of albumin and $\mathrm{A} / \mathrm{G}$ ratio in all groups were significantly decreased compared with G1 (control). But the mean values of globulin in all groups were significantly increased compared with G1 (control).

These results are in agreement with those reborted by Abdel-Hafez and Osman (2013), Hassina et al. (2013) and Baligar et al. (2014).

\subsection{Effect of Azadirachtin and Emamectin} Benzoate residues on kidney function of rats.

Serum creatinine, urea and uric acid experimental rats oral administration of both Emamectin Benzoate and Azadirachtin were determined as indicators of kidney function, since the increase in these parameters means that the kidney is less active or there is an abnormality has been occurred. The obtained results recorded in Table (3).

From the obtained results of creatinine, urea and uric acid parameters were found to be $0.73 \pm 0.04$, $19.67 \pm 1.20$ and $4.28 \pm 0.11 \mathrm{mg} / \mathrm{dl}$ for rats fed diets control, respectively. From the obtained data, it could be observed that the results of creatinine, urea and uric acid were found to be significantly increased of all groups which administrated by Emamectin Benzoate and Azadirachtin at different doses if compared with control group except G4 which showed that relatively small differences. On the other hand, the results of creatinine, urea and uric acid showed a significant increase in Azadirachtin more than Emamectin Benzoate and control. Therefore, the results of Emamectin Benzoate were lower toxic than Azadirachtin on creatinine, urea and uric acid for experimental rats. These results are in agreement with those reported by Abdel-Hafez and Osman (2013) and Baligar et al. (2014).

Table 3. Effect of Azadirachtin and Emamectin Benzoate residues on kidney function of experimental rats.

\begin{tabular}{|c|c|c|c|c|c|c|c|c|}
\hline \multirow[b]{2}{*}{ Parameter } & \multirow{2}{*}{$\begin{array}{c}\text { Period } \\
\text { for } \\
\text { dose }\end{array}$} & \multirow{2}{*}{$\begin{array}{c}\text { Control } \\
\text { G1 }\end{array}$} & \multicolumn{3}{|c|}{ Azadirachtin } & \multicolumn{3}{|c|}{ Emamectin Benzoate } \\
\hline & & & G2 & G3 & G4 & G5 & G6 & G7 \\
\hline \multirow{6}{*}{$\begin{array}{c}\text { Creatinine } \\
\text { (mg/dl } \\
\text { Urea } \\
\text { (mg/dl } \\
\text { Uric acid } \\
\text { (mg/dl }\end{array}$} & Before & $0.63 \pm 0.09^{\mathrm{aAB}}$ & $0.83 \pm 0.09^{\mathrm{aD}}$ & $0.73 \pm 0.12^{\mathrm{aB}}$ & $0.60 \pm 0.06^{\mathrm{aA}}$ & $0.63 \pm 0.09^{\mathrm{aAB}}$ & $0.67 \pm 0.03^{\mathrm{aABC}}$ & $0.77 \pm 0.15^{\mathrm{aCD}}$ \\
\hline & After & $0.73 \pm 0.04^{\text {bA }}$ & $1.63 \pm 0.06^{\mathrm{bE}}$ & $1.44 \pm 0.04^{\mathrm{bD}}$ & $1.23 \pm 0.06^{\mathrm{bC}}$ & $1.47 \pm 0.04^{\mathrm{bD}}$ & $1.27 \pm 0.03^{\mathrm{bC}}$ & $1.07 \pm 0.05^{\mathrm{bB}}$ \\
\hline & Before & $14.67 \pm 0.88^{\mathrm{aA}}$ & $20.67 \pm 1.76^{\mathrm{aC}}$ & $25.33 \pm 1.45^{\mathrm{aD}}$ & $15.33 \pm 1.20^{\mathrm{aAB}}$ & $17.33 \pm 1.76^{\mathrm{aB}}$ & $16.67 \pm 2.03^{\mathrm{aAB}}$ & $17.67 \pm 3.18^{\mathrm{aB}}$ \\
\hline & After & $19.67 \pm 1.20^{b A}$ & $60.33 \pm 0.76^{b F}$ & $48.67 \pm 0.49^{\mathrm{bE}}$ & $35.17 \pm 1.47^{\mathrm{bC}}$ & $48.67 \pm 1.31^{\mathrm{bE}}$ & $42.17 \pm 1.66^{\mathrm{bD}}$ & $30.83 \pm 1.64^{\mathrm{bB}}$ \\
\hline & Before & $4.03 \pm 0.15^{\mathrm{aC}}$ & $3.77 \pm 0.15^{\mathrm{aAB}}$ & $3.60 \pm 0.12^{\mathrm{aA}}$ & $3.87 \pm 0.09^{\mathrm{aB}}$ & $4.07 \pm 0.12^{\mathrm{aC}}$ & $4.47 \pm 0.09^{\mathrm{aD}}$ & $3.63 \pm 0.15^{\mathrm{aA}}$ \\
\hline & After & $4.28 \pm 0.11^{\mathrm{bA}}$ & $6.93 \pm 0.14^{\mathrm{bF}}$ & $6.40 \pm 0.14^{\mathrm{bE}}$ & $5.87 \pm 0.11^{\text {bD }}$ & $5.70 \pm 0.09^{\mathrm{bD}}$ & $5.10 \pm 0.06^{\mathrm{bC}}$ & $4.48 \pm 0.13^{\mathrm{bB}}$ \\
\hline
\end{tabular}

a, b \& c: There is no significant difference $(P>0.05)$ between any two means, within the same column have the same superscript letter.

A, B \& C: There is no significant difference $(P>0.05)$ between any two means for the same attribute, within the same row have the same superscript letter.

All values were expressed as mean $\pm \mathrm{SE}$ (six rats)

SE: Stander error

Before: Zero time

After: End time (two months).

G1: Control (normal diet).

G3: Administrated orally $1 / 150 \mathrm{LD}_{50}$ of Azadirachtin.

G2: Administrated orally 1/100 $\mathrm{LD}_{50}$ of Azadirachtin. G4: Administrated orally 1/225 $\mathrm{LD}_{50}$ of Azadirachtin.

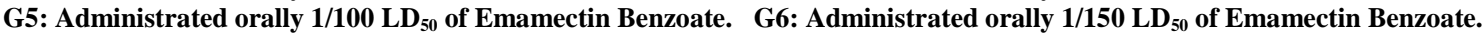

G7: Administrated orally 1/225 $\mathrm{LD}_{50}$ of Emamectin Benzoate.

\section{Effect of Azadirachtin and Emamectin} Benzoate residues on body weight of experimental rats.

Initial body weight and final body weight of rats administrated orally different doses of Emamectin Benzoate and Azadirachtin (1/100 LD $50,1 / 150$ LD $_{50}$ and $1 / 225 \mathrm{LD}_{30}$ of each) were recorded during first week and end of experimental period ( 8 week). From the data presented in Table (6). It is clear that, the initial average weight $(\mathrm{g})$ of rats were found to be (109.17) for control group. While, these values were (114.17), (111.67) and (111.67), with 1/100 LD $_{50}$, $1 / 150 \mathrm{LD}_{50}$ and1/225 $\mathrm{LD}_{50}$ of Azadirachtin and (112.50), (112.50) and (117.50) with the same dose of Emamectin Benzoate, respectively. The obtained data showed that rats fed normal basal diet had the highest total final body weight $(\mathrm{g})$ which increased from (109.17) to (261.67) after eight weeks. While, the final body weights $(\mathrm{g})$ of rats administrated orally of Emamectin Benzoate at the doses of $\left(1 / 100 \mathrm{LD}_{50}\right.$, $1 / 150 \mathrm{LD}_{50}$ and $1 / 1225 \mathrm{LD}_{50}$ ) were increased from (114.17) to (215.0), (111.67) to (226.67) and (111.67) to (233.33), respectively, and the final body weight of rats administrated orally of Azadirachtin at the same dose, were increased from (112.50), to (208.00), (112.50) to (196.0) and (117.50) to (203.33) respectively, at end of experimental period ( 8 week). On the other hand, the increase values(g) and changes $(\%)$ of body weights of rats for control group were (152.50) and (140.66). while the increase values $(\mathrm{g})$ and changes $(\%)$ of body weights of rats administrated orally of Emamectin Benzoate at the dose of $\left(1 / 100 \mathrm{LD} 50,1 / 150 \mathrm{LD}_{50}\right.$ and $\left.1 / 225 \mathrm{LD}_{50}\right)$ were (100.83) and (88.64), (115.0) and (104.21) and 
(121.67) and (110.25). respectively, while, the increase values $(\mathrm{g})$ and changes(\%) of body weights of rats administrated orally of Azadirachtin at the same dose were (95.50) and (84.99),(83.50) and (74.49) and (85.83) and (73.24) respectively, at end of experimental period (two months).

From the obtained results, could be noticed that the increasement and changes (\%) of body weights of rats for Emamectin Benzoate and Azadirachtin group had lower of control Group while, the increase and changes (\%) of body weights of rats for Emamectin Benzoate groups were higher of Azadirachtin. These results are in agreement with those reported by Hassina et al. (2013). So the results of Emamectin Benzoate were best of Azadirachtin of effect on body weight, experimental rats. So the Emamectin Benzoates were lower toxic than Azadirachtin on body weights of experimental rats.

Table 4. Effect of Azadirachtin and Emamectin Benzoate on body weight of experimental rats.

\begin{tabular}{lccccccc}
\hline \multirow{2}{*}{ Weight } & Control & \multicolumn{3}{c}{ Azadirachtin } & \multicolumn{3}{c}{ Emamectin Benzoate } \\
\cline { 2 - 8 } & G1 & G2 & G3 & G4 & G5 & G6 & G7 \\
\hline Initial (g) & $\mathbf{1 0 9 . 1 7}$ & $\mathbf{1 1 2 . 5 0}$ & $\mathbf{1 1 2 . 5 0}$ & $\mathbf{1 1 7 . 5 0}$ & $\mathbf{1 1 4 . 1 7}$ & $\mathbf{1 1 1 . 6 7}$ & $\mathbf{1 1 1 . 6 7}$ \\
Final (g) & $\mathbf{2 6 1 . 6 7}$ & $\mathbf{2 0 8 . 0 0}$ & $\mathbf{1 9 6 . 0 0}$ & $\mathbf{2 0 3 . 3 3}$ & $\mathbf{2 1 5 . 0 0}$ & $\mathbf{2 2 6 . 6 7}$ & $\mathbf{2 3 3 . 3 3}$ \\
Increase (g) & $\mathbf{1 5 2 . 5 0}$ & $\mathbf{9 5 . 5 0}$ & $\mathbf{8 3 . 5 0}$ & $\mathbf{8 5 . 8 3}$ & $\mathbf{1 0 0 . 8 3}$ & $\mathbf{1 1 5 . 0 0}$ & $\mathbf{1 2 1 . 6 7}$ \\
Changes (\%) & $\mathbf{1 4 0 . 6 6}$ & $\mathbf{8 4 . 9 9}$ & $\mathbf{7 4 . 4 9}$ & $\mathbf{7 3 . 2 4}$ & $\mathbf{8 8 . 6 4}$ & $\mathbf{1 0 4 . 2 1}$ & $\mathbf{1 1 0 . 2 5}$ \\
\hline
\end{tabular}

G1: Control (normal diet).

G3: Administrated orally 1/150 LD 50 of Azadirachtin.

G2: Administrated orally 1/100 LD 50 of Azadirachtin.

G4: Administrated orally 1/225 LD 50 of Azadirachtin.

G5: Administrated orally 1/100 LD 50 of Emamectin Benzoate. G6: Administrated orally 1/150 LD50 of Emamectin Benzoate. G7: Administrated orally 1/225 LD 50 of Emamectin Benzoate.

\section{Histopathological findings:}

4.1 Histopathological examination of rats' liver:

Group (1): The microscopic examination of the liver of rats in control group revealed nearly histologic hepatic tissues. There was no histopthological alteration observed and the normal histological structure of the central vein and surrounding hepatocytes in the parconchyma were recorded in (Fig. 1A).

Group (2): The microscopic examination of the liver of rats administrated orally $1 / 100 \mathrm{LD}_{50}$ of Azadirachtin (50 mg/kg B.wt). Congestion was detected in the central vein and sinusoids associated with apoptosis in some individual hepatocytes in association with focal inflammatory cells infiltration in the hepatic parenchyma (Fig. 1B).

Group (3): The liver of rats administrated orally 1/150 LD50 of Azadirachtin (33.3 mg/kg B.wt). The portal area showed congestion in the portal vein associated with few inflammatory cells infiltration surrounding the bile ducts (Fig. 1C).

Group (4): The liver of rats administrated orally $1 / 225 \mathrm{LD}_{50}$ of Azadirachtin $(22.2 \mathrm{mg} / \mathrm{kg} \mathrm{B} . \mathrm{wt})$. The portal area showed congestion in the portal vein associated periductal fibrosis surrounding the formed bile ducts (Fig. 1D).

Group (5): The liver of rats administrated orally $1 / 100 \mathrm{LD}_{50}$ of Emamectin Benzoate $(15 \mathrm{mg} / \mathrm{kg}$ B.wt). There were dilatation and congestion in the central and portal veins (Fig.34). Focal inflammatory cells infiltration was detected in the portal area surrounding the dilated portal vein (Fig. 1E).

Group (6): The liver of rats administrated orally $1 / 150 \mathrm{LD}_{50}$ of Emamectin Benzoate $(10 \mathrm{mg} / \mathrm{kg}$ B.wt). Congestion was noticed in the portal vein (Fig. 1F).

Group (7): The histopathological examination of the liver of rats administrated orally $1 / 225 \mathrm{LD}_{50}$ of
Emamectin Benzoate (6.7mg/kg B.wt).Dilatation and congestion were noticed in the central vein (Fig. 1G).

\subsection{Histopathological examination of rat's kidney:}

Group (1): The microscopic examination of the kidneys of rats fed on basal diet showed normal histological structure of the renal tissues. There was no histopathological alteration observed and the normal histological structure of the glomeruli and tubules at the cortex were recorded in (Fig. 2A).

Group (2): The microscopic examination of the kidney of rats administrated orally $1 / 100 \mathrm{LD}_{50}$ of Azadirachtin (50 mg B.wt). There was congestion in the cortical blood vessels (Fig. 2B).

Group (3): The kidney of rats administrated orally $1 / 150 \quad \mathrm{LD}_{50}$ of Azadirachtin $(33.3 \mathrm{mg} / \mathrm{kg}$ B.wt).Congestion was detected in the cortical blood vessels (Fig. 2C).

Group (4): The kidney of rats administrated orally $1 / 225 \mathrm{LD}_{50}$ of Azadirachtin (22.2 $\mathrm{mg} / \mathrm{kg} \mathrm{B.wt}$ ). Congestion was observed in the cortical blood vessels (Fig. 2D).

Group (5): The kidney of rats administrated orally $1 / 100 \mathrm{LD}_{50}$ of Emamectin Benzoate (15 mg B.wt). There was no histopathological alteration as recorded in (Fig. 2E).

Group (6): The kidney of rats administrated orally $1 / 150 \mathrm{LD}_{50}$ of Emamectin Benzoate (10 mg B.wt). There was mild congestion in the corticalblood vessels (Fig. 2F).

Group (7): The histopathological examination of the kidney of rats administrated orally $1 / 225 \mathrm{LD}_{50}$ of Emamectin Benzoate $(6.7 \mathrm{mg} / \mathrm{kg}$ B.wt) There was sever congestion in the cortical blood vessels (Fig. $2 \mathrm{G})$.

So we suggest that usage of Emamectin Benzoate because it less toxic to environment safety. 


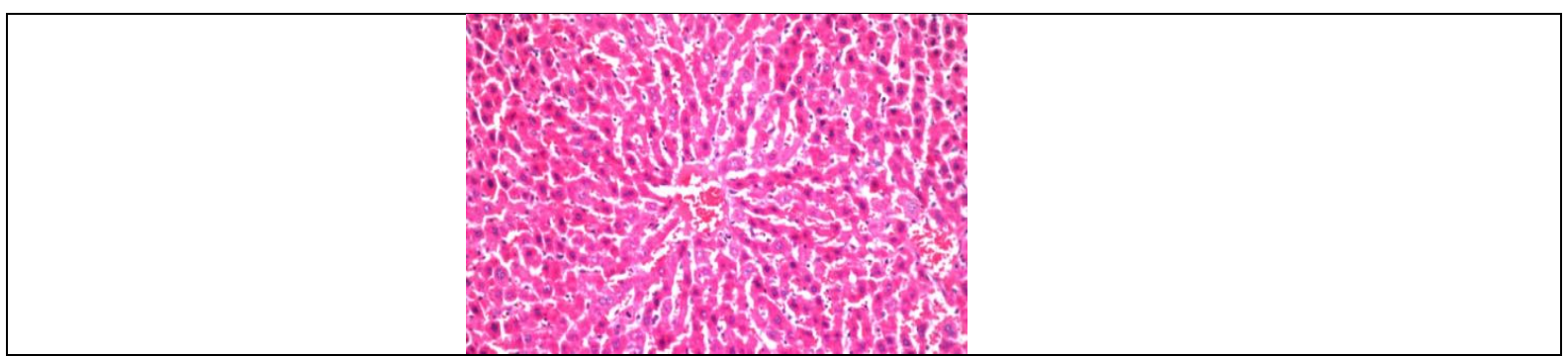

A): Liver of rats in group kept as control. Showing normal histological of the central vein and surrounding hepatocytes in hepatic parenchyma (H\&E x 40)

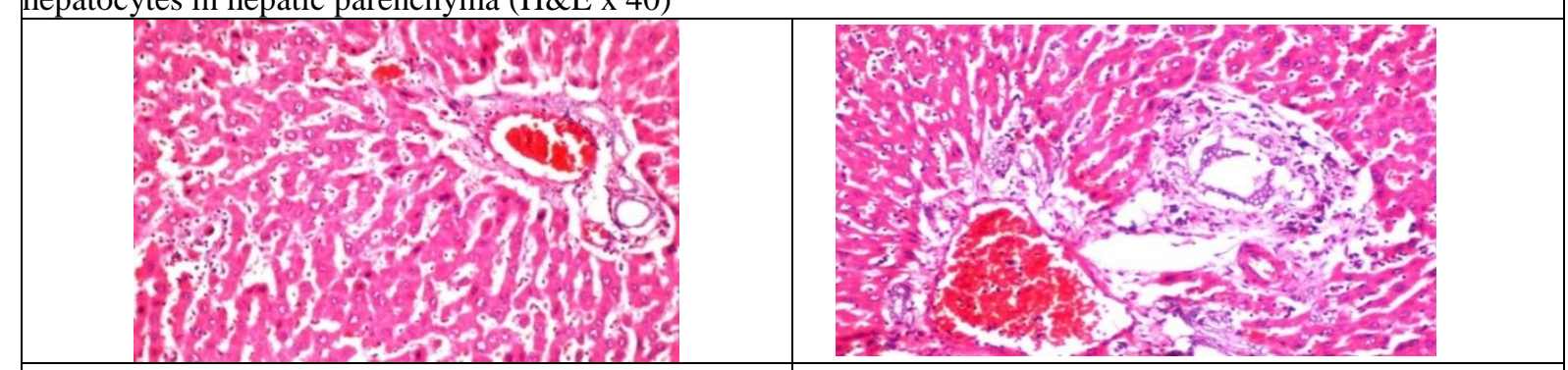

B): Liver of rats in group administrated orally 1/100 C): Liver of rats in group (3) administrated orally 1/150 $\mathrm{LD}_{50}$ of Azadirachtin (50mg/kg B. wt). Showing LD50 of Azadirachtin (33.3 mg/kg B.wt) showing congestion in portal vein and sinusoids with apoptosis congestion in portal vein with few inflammatory cells in in some individual hepatocytes in association with focal the portal area surrounding the bile duet (H\&E X 40) inflammatory cells infiltration $\mathrm{m}$ between the hepatocytes in the parenchyma (H\&E x 40).

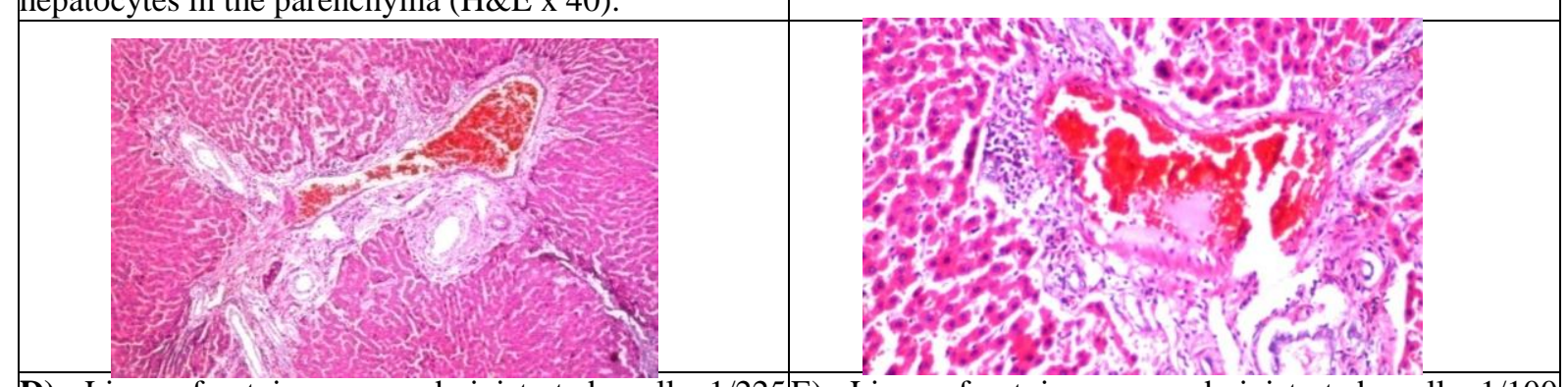

D): Liver of rat in group administrated orally 1/225 E): Liver of rat in group administrated orally $1 / 100$ LD $_{50}$ of Azadirachtin (22.2 mg B.wt). Showing LD S0 $_{50}$ of Emamectin Benzoate (15 mg B.wt). Showing congestion in portal vein with fibrosis surrounding the focal inflammatory cells infiltration in the portal area multiple newly formed bile ducts in the portal areasurrounding the dilated portal vein (H\& Ex 40)

(H\&E x 16)

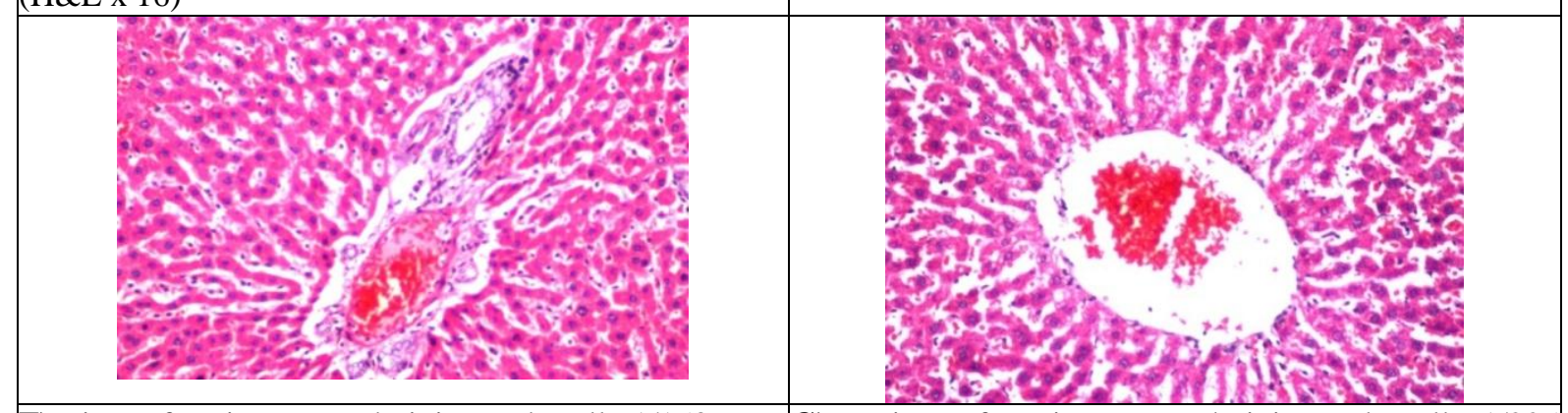

F) Liver of rat in group administrated orally $\left.1 / 150 \mathrm{LD}_{50} \mathbf{G}\right)$ : Liver of rat in group administrated orally $1 / 225$ of Emamectin Benzoate (10 mg B.wt). Showing $L_{50}$ of Emamectin Benzoate $(6.7 \mathrm{mg} / \mathrm{kg}$ B.wt). congestion in portal vein (H\&E x 40).

Showing dilatation and congestion in central vein (H\&E x 40).

Fig. (1A-G): Liver of rats in group administrated orally Azadirachtin and Emamectin Benzoate. 


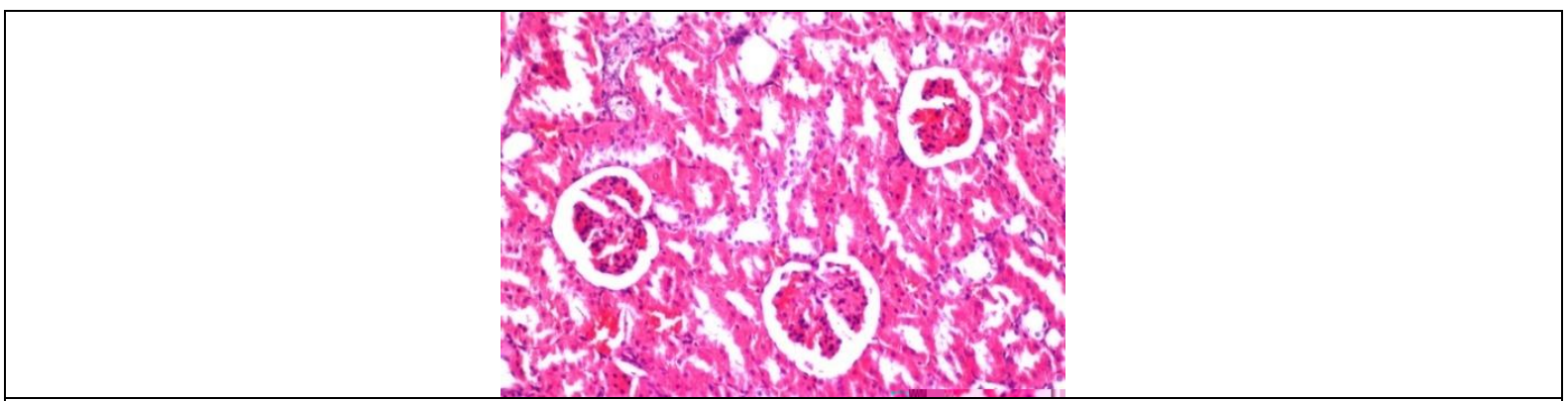

A) Kidney of rats in group kept as control showing normal histological structure of the glomeruli and tubules at the cortex (H\&E x 40)

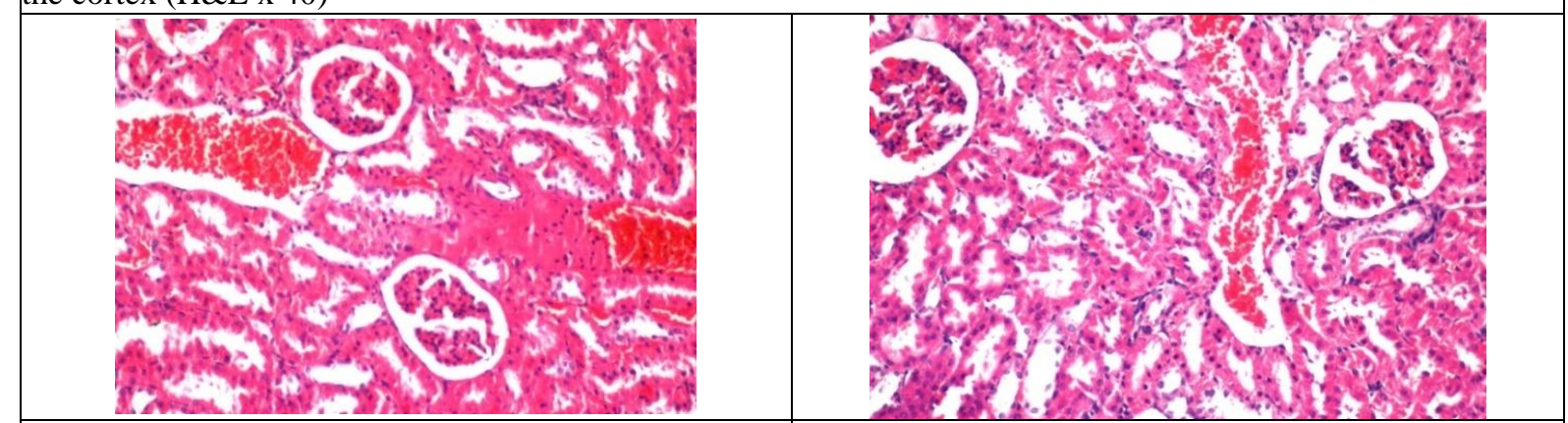

B) Kidney of rats in group administrated orally 1/100C) Kidney of rat in group administrated orally 1/150 $\mathrm{LD}_{50}$ of Azadirachtin $(50 \mathrm{mg} / \mathrm{kg}$ B.wt). Showing LD50 of Azadirachtin $(33.3 \mathrm{mg} / \mathrm{kg}$ B.wt). Showing congestion in the cortical blood vessels (H\&E x 40). congestion in cortical blood vessel and glomeruli (H\&E

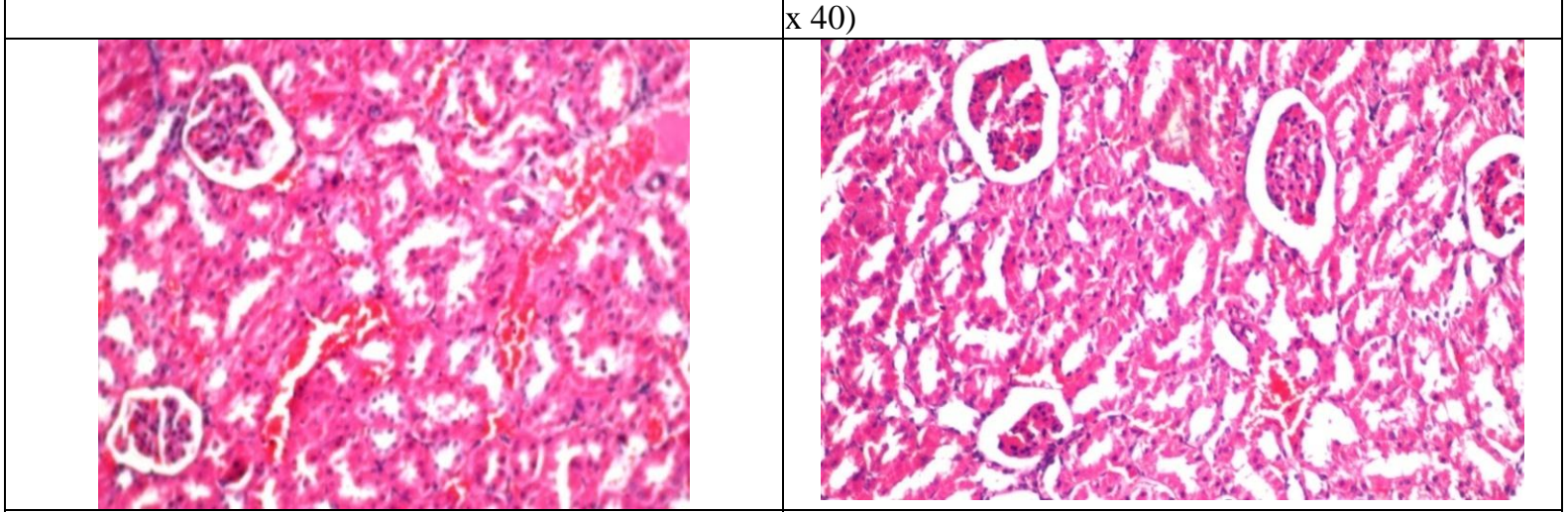

D) Kidney of rat in group administrated orally $1 / 225$ E) Kidney of rat in group administrated orally $1 / 100$ $\mathrm{LD}_{50}$ of Azadirachtin (22.2 mg B.wt).Showing LD $\mathrm{L}_{50}$ of Emamectin Benzoate $(15 \mathrm{mg} / \mathrm{g} \mathrm{B}$.wt). Showing congestion in cortical blood vessel (H\&E x 40) normal histological structure (H\&E x 40)
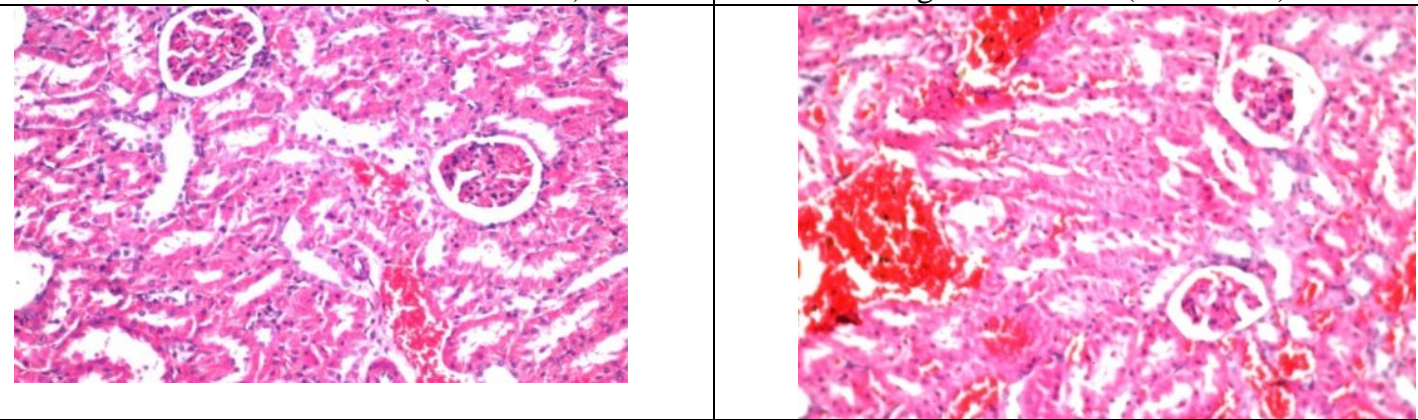

F) Kidney of rat in group administrated orally $1 / 150$ G) Kidney of rat in group administrated orally $1 / 225$ $\mathrm{LD}_{50}$ of Emamectin Benzoate $\left(10 \mathrm{mg} / \mathrm{kg} \quad\right.$ B.wt). LD $D_{50}$ of Emamectin Benzoate $(6.7 \mathrm{mg} / \mathrm{kg} \quad$ B.wt $)$. Showing mild congestion incortical blood vessels Showings sever congestion in cortical blood vessel $(H \& E \times 40)$ $(\mathrm{H} \& \mathrm{E}$ x 40)

Fig. (2A-G): Kidney of rats in group administrated orally Azadirachtin and Emamectin Benzoate. 


\section{References}

Abdel-Hafez, H.F. and Osman, H.H. (2013). Effects of pyridalyl and Emamectin benzoate on some biological and biochemical parameters of Spodoptra littoralis (Boisd.) and Albion rat, Egypt. Acad. J. Biolog. Sci., 6(3): 59-68.

Baligar, N.S.; Alalaktli, R.H.; Ahmed, M. and Ogbede, S.C.; Saidu, A.N.; Kabiru, A.Y. and Busari, M.B. (2014). Nutrient and anti-Nutrient compositions Of (Brassica Oleracae var. Capitata L.),J. Pharmacy, 5: 19-25.

Banchroft, J.D.; Stevens, A. and Turner, D.R. (1996). Theory and Practice of histological techniques. $4^{\text {th }}$ Ed.Churchil Livingestone, New York, London, San Francisco, Tokyo.

Correia, M.; Delerue-Matos, C. and Alves, A. (2000). Multi residue Methodology for pesticide screening in wines. Chromatography an 889: 5967.

Dafalla, M.B.; Konozy, E.H. and Saad, H.A. (2012). Biochemical and histological studies on the effect of azadirachta indica Seeds kernel extract on albino rats, Int. J. Med. Plants Rss., 1(6): $82-92$.

Doumas, B.T. (1975). Standard methods of protein determination. Clin. Chem., 7: 175-188.

Doumas, B.T.; Biggs, H.G.; Arends, R.L. and Pinto, P.V.C. (1971). Albumine Standard and the measurement of serum albumin with bromocresol green. Clin. Chem. Acta., 31: 87-95.

Eskenazi, B.; Rosas, L.G.; Marks, A.R.; Bradman, A.; Harley, K.; Holland, N.; Johnson, C.; Fenster, L. and Barr, D. (2008). Pesticide toxicity and the Developing brain. Basic and Clinical. Pharmacology and Toxicology, 102(2): 228-236.

Gutfinger, T. (1981). Polyphenols in Olive oils. J. Am. Oil Chem. Soc., 58: 966-986.

Haisman, P. and Muller, B.R. (1977). Glossary of clinical chemistry terms. P. 126., Butterwoth, London.

Hassina, K.O.; Camille, R.; Nadia, D.; Michel L.; Luc, H. and Abcene, B. (2013): Effect of subacute exposure to abamectin "insecticide" in liver rat (Rattus Norvegicus) Ann. Toxicol. Anal., 10: 1-8.

Henery, R.J.; Cannon, D.C. and Winkelman, J.W. (1974). Clinical chemistry: Principles and techniques, $2^{\text {nd }}$. New York, Harper and Row. P. 422-24.

Immaraju, J.A. (1998). The commercial use of azadirachtin and its integration into viable pest control programmes. J. pestic. Sci., 54, 285-289.
Ishaaya, I.; Barazani, A.; Kontsedalov and Horowitz, A.R. (2007). Insecticides with Novel modes of action: mechanism, selectivity and cross-resistance. Entomol., 37: 148-152.

Kang, H.K.; Crouch, L.S.; Bova, A.; Robinson, R.A. and Wu, J. (2001). Determination of emamectin residues in the tissues of Atlantic salmon (Salmo salar L.) using HPLC with fluorescence detection. J. Agric. Food Chem., 49: 5294-5302.

Lowry, O.J.; Rosebrough, N.J.; Parr, A.L. and Randall, R.J. (1951). Protein Measurement with the Folin phenol reagent. J. Biol. Chem., 193: 265-275.

Pang-Hang, Y.; Jian, S.; Amartalingam, R. and Choon-Fah J.B. (2008). Boric acid levels in fresh noodles and fish ball. Am. J. Agric. Biol. Sci., 3: 476-481.

Pleshkov, B.P. (1976). Practical Methods of Plant Biochemistry. Moscow: 106 (Russ).

Reitman, S. and Frankel, S. (1957). A colorimetric method for the transaminases. Am. J. Clin. Path., 221(56): 56.

Sanborn, M.; Cole, D.; Kerr, K.; Vakil, C.; Sanin, L.H. and Basil, K. (2004). Systematic review of pesticides human health effects. The Ontario, College of Family Physicians. Downloaded from http: 11 www/ocfp. On.cal local lfiles Communications Current\% 20 Issues.

Seljasena, R. and Meadow, R. (2006). Effect of neem on oviposition and egg and larval Development of Mamestra brassical: dose response, residual Activity, repellent effect and systemic activity in cabbage plants.Crop Port 25: $338-345$.

Sharma, V.; Walia, S.; Dhingra, S.; Kumar, J. and Parmar, B.S. (2006). Azadirachtin-A and tetrahydroazadirachtin-A concentrates: preparation, LC-MS characterization and insect antifeed antlIGR activity against Helicoverpa armigera (Hubner). Pest Manag. Sci., 62: 965975.

Steel, R.; Torrie, J. and Dickey, D. (1977). Principles and Procedures of Statistics: A Biometrical Approach, $3^{\text {rd }}$ Ed, McGraw-Hill, New York, NY.

Tabacco, A.; Meiattini, F.; Moda, E. and Tarlip (1979). Simplified enzymic Colormetric serum urea nitrogen determination. Clin., Chem., 25: 336-337.

Tietz, N.W.; Burtis, C.J.; Rinker, A.D.; Shuey, D. and Zygowicz, E.R. (1983). A reference method for measurement of alkaline phosphates activity in Human serum study group on alkaline phosphates. Clin. Chem., 29(25): 751-761. 
تأثير مبيدات الآداديراكتين والايمامكتين بنزوات كملوثات عضوية على فئران التجارب

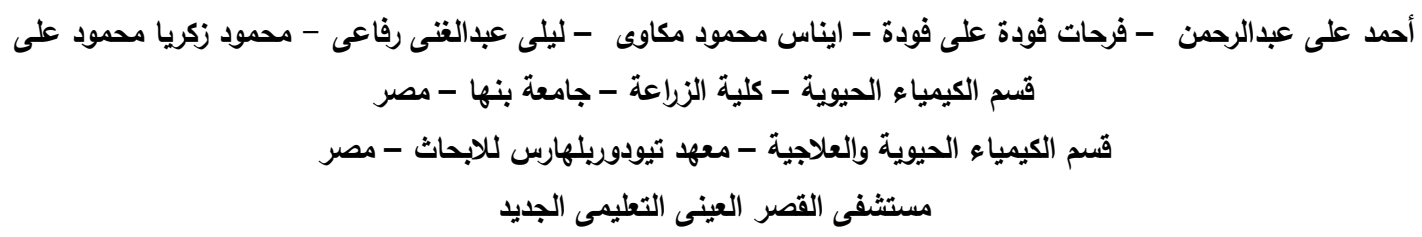

هدفت الدراسة لالقاء الضوء لدراسة كفاءة مركبين وهما الاذاديراكتين والايمامكتين بنزوات وهو احدى مشتقات المنتج الطبيعى الابامكتين على الإنى الإني

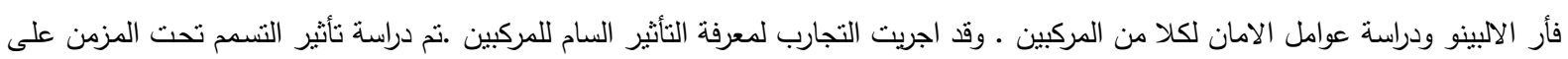

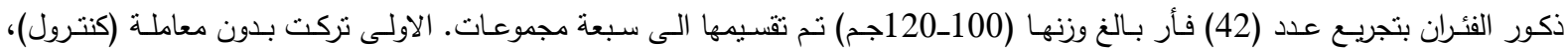

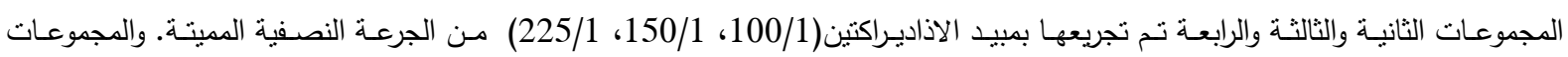
الخامسة والسادسـة والسـابعة تم تجريعها بمبيد الايمـامكتين بنزوات بنفس الجرعات الجرعات (100/1، 150/1، 225/1) من الجرعـة النصفية الميتيتة

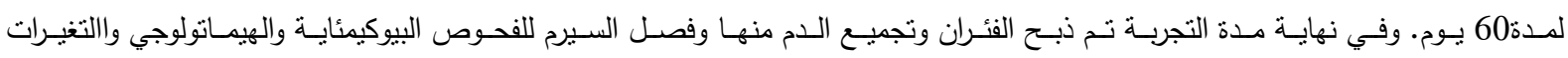
الهستوباثولوجية.

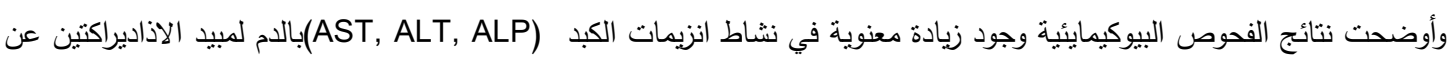

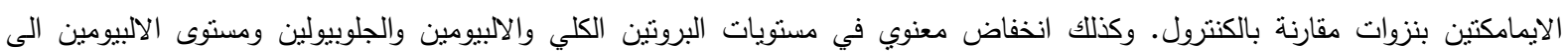

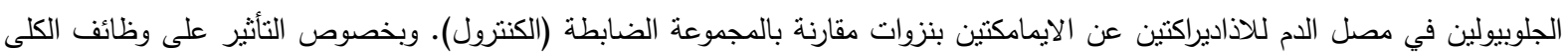

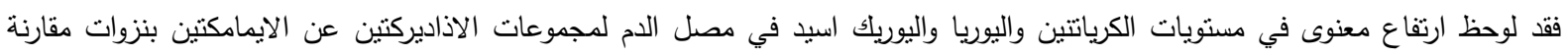

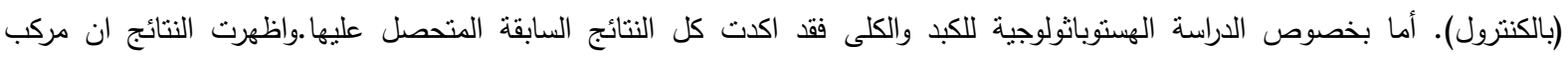

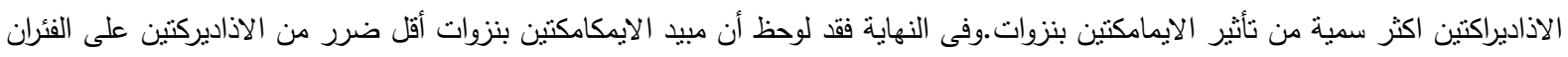

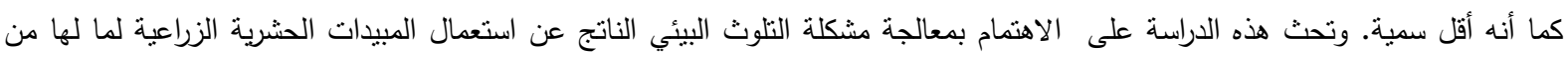

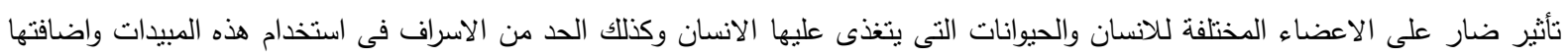
او استخدامها فى الحدود المسموح بها صحيا. 